\title{
Keterlaksanaan standar proses pada pembelajaran matematika menurut Kurikulum 2013 pada kelas XII SMA Negeri
}

\author{
Jaya Paldi ${ }^{{ }^{*}}$, Jailani ${ }^{2}$ \\ ${ }^{1}$ Program Studi S2 Pendidikan Matematika, Universitas Negeri Yogyakarta, Indonesia \\ 2 Jurusan Pendidikan Matematika, Universitas Negeri Yogyakarta, Indonesia \\ *Corresponding Author. E-mail: jaya89coy@gmail.com
}

\begin{tabular}{|c|c|}
\hline ARTICLE INFO & ABSTRACT \\
\hline $\begin{array}{l}\text { Keywords: } \\
\text { Kurikulum 2013, } \\
\text { Pemb. matematika } \\
\text { Standar proses } \\
\text { Curriculum 2013, } \\
\text { Mathematics learning } \\
\text { Process standard }\end{array}$ & $\begin{array}{l}\text { Penelitian ini bertujuan untuk mendeskripsikan keterlaksanaan standar proses pada pem- } \\
\text { belajaran matematika menurut Kurikulum } 2013 \text { pada kelas XII SMA Negeri. Penelitian ini } \\
\text { merupakan penelitian mixed method dengan desain sequential explanatory strategy. Parti- } \\
\text { sipan pada penelitian ini adalah guru matematika kelas XII SMA Negeri di Kota Pekanbaru yang } \\
\text { menerapkan Kurikulum 2013. Keterlaksanaan standar proses dinilai berdasarkan aspek peren- } \\
\text { canaan, pelaksanaan, dan penilaian pembelajaran. Analisis data deskriptif menggunakan } \\
\text { kecenderungan keterlaksanaan dalam lima kriteria, yaitu sangat baik, baik, cukup, kurang, dan } \\
\text { sangat kurang. Hasil penelitian menunjukkan bahwa keterlaksanaan standar proses menurut } \\
\text { Kurikulum } 2013 \text { pada kelas XII SMA Negeri di Kota Pekanbaru ditinjau dari aspek perencanaan, } \\
\text { pelaksanaan, dan penilaian pembelajaran adalah masuk pada kategori baik. Hasil penelitian } \\
\text { juga menunjukkan bahwa pada aspek perencanaan guru masih mengalami kendala dalam } \\
\text { penyusunan lembar kegiatan siswa, rencana pelaksanaan pembelajaran, serta perencanaan } \\
\text { alokasi waktu. Pada aspek pelaksanaan pembelajaran, masih terdapat kendala yaitu pada } \\
\text { kemauan guru untuk menerapkan pendekatan saintifik, terutama pada tahap menanya dan } \\
\text { menalar. Adapun pada aspek penilaian, guru masih mengalami kendala terkait penilaian sikap } \\
\text { dan keterampilan. }\end{array}$ \\
\hline
\end{tabular}

This study aimed to describe the implementation of process standard in mathematics learning according to the Curriculum 2013 in 12th-grade of public senior high school. This research was mixed-method research with a sequential explanatory strategy design. Participants in this study were mathematics teachers of 12th-grade of public senior high school in Pekanbaru City, Indonesia who applied the Curriculum 2013. The process standard was assessed based on aspects of planning, implementing, and assessment of learning. Descriptive data analysis used the tendency of implementation in five criteria, namely very good, good, enough, less, and very less. The results showed that the implementation of process standard according to the Curriculum 2013 in class 12th-grade of public senior high school in Pekanbaru City in terms of planning, implementation, and assessment of learning were included in the good category. The results of the study also showed that in the aspect of planning, the teacher was still experiencing problems in the preparation of students' worksheet, lesson plan, and time allocation planning. In the aspect of implementing learning, there were still obstacles, namely the teacher's willingness to apply a scientific approach, especially at the questioning and reasoning stages. As for the aspects of assessment, teachers still experience obstacles related to the assessment of attitudes and skills.

\section{SCAN ME}

\section{How to Cite:}

Paldi, J., \& Jailani, J. (2019). Keterlaksanaan standar proses pada pembelajaran matematika menurut Kurikulum 2013 pada kelas XII SMA Negeri. PYTHAGORAS: Jurnal Pendidikan Matematika, 14(1), 80-91. doi: https://doi.org/10.21831/pg.v14i1.21220 


\section{PENDAHULUAN}

Pendidikan merupakan aspek penting untuk menunjang kemajuan suatu negara, termasuk di Indonesia. Pendidikan nasional di Indonesia yang berdasarkan Pancasila dan Undang-Undang Dasar Negara Republik Indonesia Tahun 1945 pada hakikatnya berfungsi untuk mengembangkan kemampuan dan membentuk watak, serta peradaban bangsa yang bermartabat dalam rangka mencerdaskan kehidupan bangsa, bertujuan untuk mengembangkan potensi peserta didik agar menjadi manusia yang beriman dan bertakwa kepada Tuhan Yang Maha Esa, berakhlak mulia, sehat, berilmu, cakap, kreatif, mandiri, dan menjadi warga negara yang demokratis serta bertanggung jawab. Dalam mengemban fungsi tersebut pemerintah menyelenggarakan suatu sistem pendidikan nasional sebagaimana tercantum dalam Undang-Undang Nomor 20 Tahun 2003 tentang Sistem Pendidikan Nasional (Republik Indonesia, 2003).

Pendidikan nasional harus mampu menjamin pemerataan kesempatan pendidikan, peningkatan mutu dan relevansi serta efisiensi manajemen pendidikan. Pemerataan kesempatan pendidikan diwujudkan dalam program wajib belajar 9 tahun. Peningkatan mutu pendidikan diarahkan untuk meningkatkan kualitas manusia Indonesia seutuhnya melalui olah hati, olah pikir, olah rasa dan olah raga agar memiliki daya saing dalam menghadapi tantangan global. Peningkatan relevansi pendidikan dimaksudkan untuk menghasilkan lulusan yang sesuai dengan tuntutan kebutuhan berbasis potensi sumber daya alam Indonesia. Peningkatan efisiensi manajemen pendidikan dilakukan melalui penerapan manajemen berbasis sekolah dan pembaharuan pengelolaan pendidikan secara terencana, terarah, dan berkesinambungan.

Perubahan pendidikan yang bersifat mendasar diperlukan dalam era globalisasi ini. Adapun perubahan tersebut antara lain, perubahan dari pandangan kehidupan masyarakat lokal ke masyarakat global, perubahan dari kohesi sosial menjadi partisi demokratis, dan perubahan dari pertumbuhan ekonomi ke perkembangan kemanusiaan. Dalam melaksanakan perubahan di bidang pendidikan tersebut, sejak tahun 2008 UNESCO telah mengemukakan dua basis landasan yaitu, pertama pendidikan harus diletakkan pada empat pilar yaitu belajar mengetahui (learning to know), belajar melakukan (learning to do), belajar hidup dalam kebersamaan (learning to live together), dan belajar menjadi diri sendiri (learning to be), kedua, belajar seumur hidup (life-long learning) (Muskin, 2015). Kedua hal tersebut tentuya harus dikembangkan dalam proses pendidikan. Meskipun demikian, perubahan pada bidang pendidikan juga harus tetap dilandasi oleh semangat membentuk nilai-nilai karakter bangsa (Zurqoni, Retnawati, Apino, \& Anazifa, 2018; Zurqoni, Retnawati, Arlinwibowo, \& Apino, 2018).

Kualitas pendidikan di Indonesia saat ini belum begitu baik. Menurut laporan UNESCO (2012) pendidikan Indonesia berada di peringkat ke-64 untuk pendidikan di seluruh dunia dari 120 negara. Education Development Index (EDI) Indonesia pada tahun 2011 berada pada peringkat ke-69 dari 127 negara (UNESCO, 2012). Berdasarkan data-data tersebut, pemerintah perlu meningkatkan kualitas pendidikan sebagai upaya mewujudkan salah satu amanat pembukaan Undang-Undang Dasar Republik Indonesia Tahun 1945, yakni mencerdaskan kehidupan bangsa. Pemerintah perlu membenahi sistem pendidikan nasional agar tujuan pendidikan nasional yakni untuk mengembangkan potensi peserta didik agar menjadi manusia yang beriman dan bertakwa kepada Tuhan Yang Maha Esa, berakhlak mulia, sehat, berilmu, cakap, kreatif, mandiri, dan menjadi warga negara yang demokratis serta bertanggung jawab (Sanjaya, 2010, p.65) dapat tercapai.

Salah satu upaya perbaikan pendidikan yang dapat ditempuh yaitu melalui pembenahan kurikulum pendidikan. Baik buruknya pendidikan tentu tidak terlepas dari kurikulum yang merupakan alat untuk mencapai tujuan pendidikan (Dakir, 2010, p.1). Kurikulum adalah seperangkat rencana dan pengaturan mengenai isi dan bahan pelajaran serta cara yang digunakan sebagai pedoman penyelenggara kegiatan belajar mengajar (Dakir, 2010, p.1). Pengembangan kurikulum merupakan konsekuensi dari perkembangan IPTEK, perubahan sistem politik, sosial budaya, dan ekonomi. Kurikulum yang merupakan gambaran bahan tertulis dalam melaksanakan pembelajaran oleh pendidik (guru) bersama peserta didik (siswa), senantiasa berkembang secara dinamis sesuai dengan tuntutan perkembangan zaman, dengan tujuan agar output yang dihasilkan nanti mampu bersaing dengan negara lain di era globalisasi.

Kemampuan siswa saat ini masih tertinggal bila dibandingkan dengan negara negara berkembang lainnya. Hal tersebut dapat terlihat dari hasil studi internasional seperti Programme for International Student Assessment (PISA) dan Trends in International Mathematics and Science Study (TIMSS). Dalam keikutsertaan Indonesia pada studi PISA tahun 2015, untuk kemampuan matematika Indonesia hanya menempati peringkat ke 115 dari 124 negara peserta (OECD, 2016). Adapun dalam keikutsertaan Indonesia pada TIMSS tahun 2015, Indonesia hanya 
berada pada peringkat ke 44 dari 49 negara peserta (Mullis, Martin, Foy, \& Hooper, 2016). Hal ini sebagai gambaran kualitas pendidikan Indonesia yang harus segera diperbaiki secara keseluruhan, baik dalam pengetahuan, sikap maupun keterampilan agar pembangunan di segala bidang dapat segera terlaksana. Berbagai permasalahan tersebut membuat pemerintah akhirnya mengembangkan kurikulum baru yaitu Kurikulum 2013.

Elemen perubahan pada Kurikulum 2013 meliputi empat standar pendidikan, yakni Standar Kompetensi Lulusan (SKL), Standar Proses, Standar Isi, dan Standar Penilaian yang dirumuskan dalam 7 elemen yakni, kompetensi lulusan, kedudukan mata pelajaran, pendekatan, struktur kurikulum (mata pelajaran dan alokasi waktu), proses pembelajaran, penilaian, dan ekstrakurikuler. Dalam perubahan proses pembelajaran, dilengkapi dengan mengamati, menanya, mengolah, menalar, menyajikan, menyimpulkan dan mencipta (Hidayat, 2013, p.126). Dalam penelitian ini, peneliti hanya menilai keterlaksanaan standar proses, karena menurut peneliti semua standar dalam proses pembelajaran terangkum dalam standar proses. Menurut Permendikbud Nomor 65 Tahun 2013 tentang standar proses, disebutkan bahwa cakupan standar proses meliputi perencanaan pembelajaran, pelaksanaan pembelajaran, dan penilaian pembelajaran (Kemendikbud, 2016).

Perubahan elemen standar proses pada Kurikulum 2013 membuat guru yang selama ini menggunakan penilaian tradisional harus mengubah penilaiannya yaitu menjadi penilaian autentik berdasarkan tuntutan kurikulum. Penilaian autentik pada Kurikulum 2013 yaitu seperti yang dinyatakan Mulyasa $(2013$, p.66) dari yang berfokus pada pengetahuan melalui penilaian output menjadi berbasis kemampuan melalui penilaian proses, portofolio dan penilaian output secara utuh dan menyeluruh. Perubahan standar penilaian pada Kurikulum 2013 mengakibatkan ikut berubahnya sistem penilaian yang dilakukan guru. Guru yang semula terbiasa mengolah nilai hanya pada domain pengetahuan, berdasarkan tes saja menjadi perlu untuk memperhatikan domain keterampilan serta sikap. Sesuai dengan penelitian Abrory (2014) tentang evaluasi implementasi Kurikulum 2013 menyebutkan bahwa kualitas penilaian dalam proses pembelajaran masih kurang. Pada Kurikulum 2013, guru tidak hanya dituntut untuk melaksanakan penilaian kognitif (pengetahuan) dan psikomotor (keterampilan) saja, tetapi juga melaksanakan penilaian afektif (sikap). Penilaian sikap terhadap siswa dapat dilakukan jika guru mengenal satu persatu kepribadian/sikap masing-masing siswa. Pada prakteknya, guru memerlukan waktu yang tidak singkat dalam mengenal/mengetahui sikap siswa.

Implementasi suatu kebijakan baru tentu ada pihak-pihak yang pro dan kontra sebagai konsekuensinya. Berbagai kendala muncul pada awal implementasi Kurikulum 2013. Susanah dan Jailani (2016) menyatakan bahwa pengetahuan guru yang masih sangat kurang tentang Kurikulum 2013 yang diantaranya juga termasuk pengetahuan tentang standar isi dan standar proses. Sementara Enika (2015) menyatakan bahwa masih terdapat banyak kendala dalam menyusun rencana pelaksanaan pembelajaran yang sesuai dengan Kurikulum 2013. Kristiyani (2015) menambahkan bahwa sebagian besar guru menyusun RPP dari hasil MGMP. Sementara dalam pelaksanaan pembelajaran terdapat banyak kendala terutama pada pendekatan saintifik. Secara umum, kendala dalam implementasi Kurikulum 2013 terdapat pada aspek persiapan yaitu menyusun RPP, aspek pelaksanaan yaitu pada penggunaan pendekatan dan metode Kurikulum 2013, serta aspek penilaian yang terdiri dari penilaian sikap, pengetahuan, dan keterampilan. Hal tersebut terjadi dikarenakan karena waktu yang kurang dalam memahami serta mengimplementasi sebuah kurikulum yang baru.

Sementara menurut Retnawati (2015), hambatan guru matematika dalam menerapkan kurikulum baru meliputi: a) pelatihan dan sosialisasi belum dapat memberikan pemahaman yang baik dan menyeluruh pada guru mengenai Kurikulum 2013; b) guru kesulitan mengatur waktu pada perencanaan pembelajaran, merencanakan pembelajaran, merencanakan penilaian sikap, dan memilah pengetahuan dan keterampilan pada penyusunan instrumen penilaian; c) waktu terbatas dalam pelaksanaan pembelajaran serta kesulitan dalam menyusun perangkat dan mengaktifkan siswa dalam pembelajaran; d) penilaian yang rumit dan perlu waktu yang lama untuk menyusun laporan. Selain itu, penelitian Festiyed (2013) menyatakan bahwa aspek sarana prasarana menjadi kunci dalam keberhasilan suatu kurikulum. Hal tersebut jelas menunjukkan bahwa implementasi Kurikulum 2013 belum berjalan sebagai mana mestinya.

Berdasarkan wawancara yang dilakukan kepada 3 orang guru matematika di Kota Pekanbaru, guru merasa bahwa komponen Kurikulum 2013 lebih sulit dari kurikulum sebelumnya (Kurikulum Tingkat Satuan Pendidikan [KTSP]). Selain penilaian yang sulit dipahami, kompetensi inti dan kompetensi dasar menjadi hal baru bagi guru sehingga dirasa sulit untuk dipahami secara utuh. Hal ini juga disebabkan karena guru belum membaca dokumen Kurikulum 2013 secara detail dan menyeluruh. Meskipun demikian, dengan adanya pelatihan dan forum seperti 
Jaya Paldi, Jailani

MGMP, guru terbantu untuk mampu menyusun perangkat dan komponen dengan baik, meskipun guru membutuhkan waktu dan usaha lebih dalam proses pembuatannya.

Pada penyelenggaraan Kurikulum 2013 di SMA, di antara kelas X, XI, dan XII, siswa kelas XII merupakan siswa yang paling lama merasakan bagaimana keterlaksanaan Kurikulum 2013 dibandingkan dua tingkat kelas lainnya. Siswa kelas XII sudah hampir tiga tahun merasakan, sedangkan siswa kelas XI selama satu tahun dan siswa kelas X bahkan belum merasakan karena baru masuk sekolah. Penelitian yang dilakukan oleh Ayu dan Dhoriva (2015) menyatakan bahwa banyak materi kelas XII yang sulit diselesaikan. Oleh karena itu, pelaksanaan Kurikulum 2013 pada kelas XII harus lebih diperhatikan. Secara teori, pembelajaran pada Kurikulum 2013 menekankan penerapan pendekatan saintifik. Namun, berdasarkan wawancara dengan guru dan siswa pembelajaran di kelas XII sendiri cenderung berupa drill soal latihan ujian nasional. Fokus pemberian materi juga berkutat pada materi-materi yang diujikan dalam ujian nasional, untuk materi lainnya siswa merasa tidak masalah jika tidak menguasai materi tersebut.

Berdasarkan latar belakang permasalahan dan kajian teori yang telah dikemukakan sebelumnya, dapat dipahami bahwa penerapan Kurikulum 2013 dalam pembelajaran matematika, terutama pada kelas XII SMA perlu mendapat perhatian khusus. Salah satu hal penting yang harus menjadi fokus perhatian adalah terkait dengan keterlaksanaan standar proses pembelajaran, sebagaimana telah diatur pada Kurikulum 2013. Keterlaksanaan standar proses menjadi salah satu faktor kunci untuk mencapai tujuan pembelajaran matematika di Indonesia. Dengan demikian penelitian ini bertujuan untuk mendeskripsikan keterlaksanaan standar proses pada pembelajaran matematika menurut Kurikulum 2013 pada kelas XII SMA Negeri.

\section{METODE}

Jenis penelitian ini adalah penelitian deskriptif dengan metode penelitian kombinasi (mixed methods). Dalam penelitian ini, hasil dari penelitian kuantitatif digunakan sebagai landasan untuk melakukan penelitian lebih mendalam secara kualitatif. Penelitian dengan pendekatan kuantitatif dilakukan dengan metode survei. Subjek atau partisipan penelitian ini adalah guru matematika kelas XII SMA Negeri di Kota Pekanbaru, Provinsi Riau, yang telah mengimplementasikan Kurikulum 2013 yang berjumlah 30 guru. Sampel penelitian kuantitatif, telaah dokumen, dan observasi menggunakan metode sensus, sehingga jumlah sampel merupakan jumlah keseluruhan partisipan. Sedangkan sampel penelitian untuk memperoleh data kualitatif adalah delapan guru untuk teknik wawancara yang dipilih menggunakan teknik purposive sampling.

\section{Prosedur}

Prosedur penelitian dengan sequential explanatory strategy yang diadaptasi dari Creswell (2009, p.210). Pengumpulan data kuantitatif dilakukan dilakukan terlebih dahulu. Pengumpulan data kuantitatif dilakukan menggunakan angket, sedangkan pengumpulan data kualitatif dilakukan dengan telaah dokumen, observasi, dan wawancara. Hasil analisis data kuantitatif digunakan sebagai dasar pada pengumpulan data kualitatif. Pada penelitian ini, pengumpulan data kualitatif bertujuan untuk memperkuat data kuantitatif. Data kuantitatif dan kualitatif dianalisis untuk digabungkan dan dibandingkan, sehingga dapat ditemukan data kualitatif mana yang memperkuat, memperluas dan menggugurkan data kuantitatif. Data kuantitatif disajikan dalam bentuk tabel atau grafik dan dilengkapi dengan data kualitatif. Setelah hasil penelitian diperoleh, kemudian dilakukan analisis dan penarikan kesimpulan.

\section{Data, Instrumen, dan Teknik Pengumpulan Data}

Keterlaksanaan standar proses pada pembelajaran matematika menurut Kurikulum 2013 pada kelas XII SMAN di Kota Pekanbaru ditinjau dari 3 aspek yaitu aspek perencanaan, pelaksanaan, dan penilaian pembelajaran. Aspek perencanaan terdiri dari kemampuan menyusun Rencana Pelaksanaan Pembelajaran (RPP) dan Lembar Kegiatan Siswa (LKS). Instrumen untuk mengukur aspek ini adalah instrumen angket dan telaah dokumen yang terdiri dari 17 butir pernyataan untuk RPP dan 9 butir pernyataan untuk LKS. Selain instrumen angket, aspek ini juga menggunakan instrumen telaah dokumen Rencana Pelaksanaan Pembelajaran (RPP) dan Lembar Kerja Siswa (LKS) untuk semua responden. Instrumen ini digunakan untuk mengukur keterampilan merencanakan pembelajaran. Aspek pelaksanaan terdiri dari keterampilan melaksanakan pembelajaran dan kesesuaian dengan RPP. Aspek pelaksanaan terdiri dari berbagai instrumen yaitu instrumen angket yang digunakan sebagai penilaian diri dalam menyiapkan pembelajaran yang terdiri 40 butir pernyataan. Instrumen angket ini menggunakan skala Guttman 
yang terdiri dari dua opsi jawaban. Selain itu, terdapat instrumen pedoman observasi untuk mengukur keterampilan melaksanakan pembelajaran. Aspek penilaian pembelajaran diukur melalui instrumen angket menggunakan skala Likert yang terdiri dari 30 butir. Instrumen terakhir yang digunakan dalam penelitian ini adalah instrumen wawancara yang bertujuan untuk mengungkap semua aspek tersebut.

\section{Teknik Analisis Data}

Berdasarkan jenis datanya, teknik analisis data yang digunakan dalam penelitian ini adalah teknik analisis data deskriptif kuantitatif dan deskriptif kualitatif. Analisis deskriptif kuantitatif disajikan dalam bentuk tabel yang memuat nilai yang sudah dikonversi dalam skala 0-100. Analisis deskriptif disajikan dalam bentuk tabel yang memuat nilai yang diperoleh dari responden. Keterlaksanaan standar proses ditentukan berdasarkan tingkat kecenderungan dengan melakukan kategorisasi pada variabel. Karena itu, perlu ditentukan dahulu nilai konversi masingmasing sub variabel sebagai kriteria. Tingkat kecenderungan dibagi dalam lima kategori seperti tampak pada Tabel 1.

Tabel 1. Kriteria Penilaian

\begin{tabular}{ll}
\hline Nilai & Kriteria \\
\hline$X>90$ & Sangat Baik \\
$75<X \leq 90$ & Baik \\
$60<X \leq 75$ & Cukup \\
$50<X \leq 60$ & Kurang \\
$X \leq 50$ & Sangat Kurang \\
\hline
\end{tabular}

Keterangan: $X=$ Nilai Responden $=\frac{\text { skor responden }}{\text { skor maksimum }} \times 100$

Data kualitatif yang diperoleh dari hasil telaah dokumen, observasi, dan wawancara dianalisis dengan analisis model interaktif (interactive model) yang terdiri dari tiga komponen analisis yaitu data reduction (reduksi data), data display (penyajian data), dan conclusion drawing and verification (penarikan kesimpulan atau verifikasi) (Miles \& Huberman, 1994, pp. 10-12). Teknik analisis data di atas dapat ditunjukkan dalam Gambar 1.

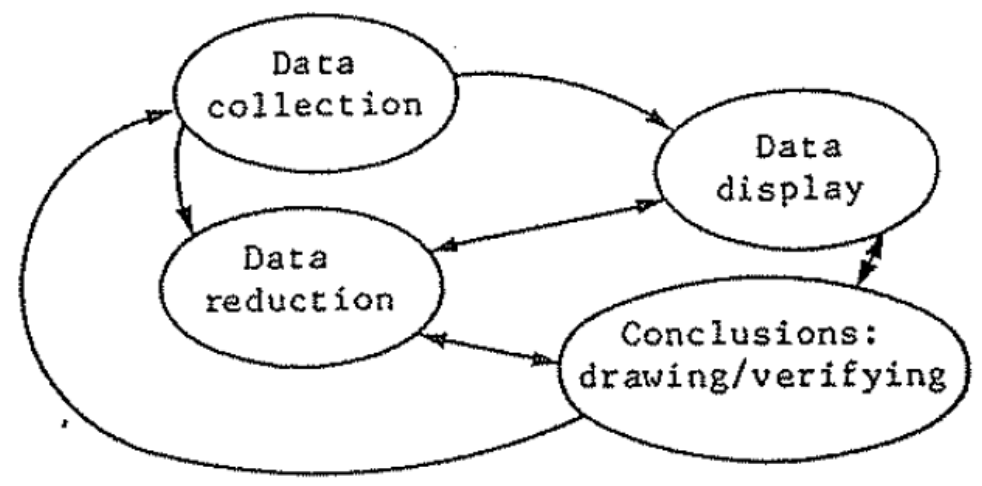

Gambar 1. Komponen Analisis Data Model Interaktif

\section{HASIL DAN PEMBAHASAN}

Hasil penelitian menunjukkan bahwa secara keseluruhan keterlaksanaan standar proses dalam pembelajaran matematika menurut Kurikulum 2013 pada kelas XII SMA Negeri di Kota Pekanbaru masuk pada kategori Baik. Adapun informasi lengkap terhadap hal tersebut disajikan pada Tabel 2. Tabel 2 memberikan gambaran bahwa dari 30 guru, $7 \%$ atau 2 guru kemampuannya dalam melaksanakan standar proses masuk dalam kategori sangat baik. Sementara $83 \%$ atau 25 guru masuk dalam kategori baik, sedangkan sisanya $10 \%$ atau 3 guru masuk dalam kategori cukup. Data tersebut menunjukkan bahwa tidak ada guru yang masuk dalam kategori kurang dan sangat kurang. Data tersebut juga menunjukkan bahwa keterlaksanaan standar proses pada pembelajaran matematika menurut Kurikulum 2013 pada kelas XII SMA Negeri di Kota Pekanbaru sebanyak lebih dari 50\% guru masuk dalam kategori baik. 
PYTHAGORAS: Jurnal Pendidikan Matematika, 14 (1), 2019 - 85

Jaya Paldi, Jailani

Tabel 2. Kemampuan Guru dalam Melaksanakan Standar Proses Pada Pembelajaran Matematika

\begin{tabular}{llll}
\hline Kriteria & Nilai & Jumlah & Presentase \\
\hline$X>90$ & Sangat Baik & 2 & $7 \%$ \\
$75<X \leq 90$ & Baik & 25 & $83 \%$ \\
$60<X \leq 75$ & Cukup & 3 & $10 \%$ \\
$50<X \leq 60$ & Kurang & 0 & $0 \%$ \\
$X \leq 50$ & Sangat Kurang & 0 & $0 \%$ \\
\hline Total & & 30 & $100 \%$ \\
\hline
\end{tabular}

Berikut disajikan secara rinci data komponen yang mendukung keterlaksanaan standar proses pada pembelajaran matematika menurut Kurikulum 2013 pada kelas XII SMA Negeri di Kota Pekanbaru, yaitu perencanaan pembelajaran, pelaksanaan pembelajaran, dan penilaian pembelajaran.

\section{Perencanaan Pembelajaran}

Perencanaan pembelajaran matematika menurut Kurikulum 2013 pada kelas XII SMA Negeri dinilai dari kualitas RPP dan LKS. Distribusi frekuensi untuk komponen perencanaan pembelajaran dapat dilihat pada Tabel 3.

Tabel 3. Kemampuan Guru dalam Perencanaan Pembelajaran Matematika

\begin{tabular}{llll}
\hline Kriteria & Nilai & Jumlah & Presentase \\
\hline$X>90$ & Sangat Baik & 1 & $3 \%$ \\
$75<X \leq 90$ & Baik & 23 & $77 \%$ \\
$60<X \leq 75$ & Cukup & 6 & $20 \%$ \\
$50<X \leq 60$ & Kurang & 0 & $0 \%$ \\
$X \leq 50$ & Sangat Kurang & 0 & $0 \%$ \\
\hline Total & & 30 & $100 \%$ \\
\hline
\end{tabular}

Tabel 3 memberikan gambaran bahwa dari 30 guru, $3 \%$ atau 1 guru masuk dalam kategori sangat baik. Sementara $77 \%$ atau 23 guru masuk dalam kategori baik. Sedangkan sisanya $20 \%$ atau 6 guru masuk dalam kategori cukup. Data tersebut menunjukkan bahwa tidak ada guru yang masuk dalam kategori kurang dan sangat kurang. Data tersebut menunjukkan bahwa lebih dari 50\% guru kemampuannya dalam membuat perencanaan pembelajaran matematika menurut Kurikulum 2013 pada kelas XII SMA Negeri di Kota Pekanbaru masuk dalam kategori baik. Temuan ini tentunya sejalan dengan hasil penelitian Putri (2015) bahwa dalam kurun waktu 2 tahun implementasi Kurikulum 2013 untuk guru matematika SMA sudah ada peningkatan kualitas dalam menyusun perencanaan pembelajaran.

Secara umum RPP yang dibuat juga sudah dalam kategori baik. Perencanaan tersebut dinilai dari kemampuan guru menyusun RPP dan LKS yang sesuai dengan Kurikulum 2013. Berdasarkan telaah dokumen juga diketahui bahwa masih terdapat RPP yang masih masuk kategori kurang karena ada beberapa langkah yang belum mengintegrasikan pendekatan saintifik dan model yang digunakan. Selain itu, masih ada beberapa indikator pencapaian kompetensi yang belum menggunakan kata kerja operasional. Dalam penyusunan LKS, guru juga kurang memperhatikan aspek-aspek dalam pembuatan LKS, sehingga LKS hanya berisikan soal-soal tanpa memperhatikan model/metode yang digunakan.

\section{Pelaksanaan Pembelajaran}

Pelaksanaan pembelajaran matematika menurut Kurikulum 2013 pada kelas XII SMA Negeri terdiri dari keterampilan guru dalam melaksanakan pembelajaran dan kesesuaiannya dengan RPP yang telah dibuat. Distribusi frekuensi kemampuan guru dalam dalam melaksanakan pembelajaran dapat dilihat pada Tabel 4 . Tabel 4 memberikan gambaran bahwa dari 30 guru, 63\% atau 19 guru kemampuannya dalam melaksanakan pembelajaran masuk pada kategori baik. Adapun sisanya yaitu sebanyak $37 \%$ atau 11 guru masuk dalam kategori cukup. Data pada Tabel 4 juga menunjukkan tidak ada guru yang masuk dalam kategori sangat baik, kurang, dan sangat kurang. Dengan demikian dapat disimpulkan bahwa lebih dari 50\% guru kemampuannya dalam melaksanakan pembelajaran matematika menurut Kurikulum 2013 pada kelas XII SMA Negeri di Kota Pekanbaru berada pada kategori 
kategori baik. Temuan ini sejalan dengan hasil penelitian Putri (2015) bahwa dalam kurun waktu 2 tahun implementasi Kurikulum 2013 untuk guru matematika SMA sudah ada peningkatan kualitas dalam melaksanakan pembelajaran yang sesuai dengan Kurikulum 2013. Dalam penelitian tersebut, pelaksanaan dinilai dari kemampuan melaksanakan proses pembelajaran dan kesesuaian dengan RPP menurut Kurikulum 2013.

Tabel 4. Kemampuan Guru dalam Pelaksanaan Pembelajaran Matematika

\begin{tabular}{llll}
\hline Kriteria & Nilai & Jumlah & Persentase \\
\hline$X>90$ & Sangat Baik & 0 & $0 \%$ \\
$75<X \leq 90$ & Baik & 19 & $63 \%$ \\
$60<X \leq 75$ & Cukup & 11 & $37 \%$ \\
$50<X \leq 60$ & Kurang & 0 & $0 \%$ \\
$X \leq 50$ & Sangat Kurang & 0 & $0 \%$ \\
\hline Total & & 30 & $100 \%$ \\
\hline
\end{tabular}

Berdasarkan data observasi diketahui bahwa 22 guru telah menggunakan pendekatan saintifik dan sisanya 8 guru menggunakan pendekatan belajar yang lain. Selain itu, juga diketahui bahwa masih banyak guru yang kesulitan dalam mendorong siswa untuk bertanya dan menalar. Banyak guru juga yang kurang memperhatikan langkah-langkah pembelajaran yang tertuang di RPP secara rinci karena menganggap bahwa yang penting materi tersampaikan dan secara garis besar pembelajaran sesuai dengan RPP yang telah dibuat.

\section{Penilaian Pembelajaran}

Keterlaksanaan standar proses ditinjau dari kemampuan guru dalam melaksanakan penilaian menurut Kurikulum 2013 diukur dari kemampuan guru dalam mengembangkan instrumen penilaian dan penggunaan teknik asesmen yang tepat dalam pembelajaran. Adapun distribusi frekuensi untuk komponen penilaian pembelajaran matematika menurut Kurikulum 2013 pada kelas XII SMA Negeri dapat dilihat pada Tabel 5.

Tabel 5. Kemampuan Guru dalam Penilaian Pembelajaran Matematika

\begin{tabular}{llll}
\hline Kriteria & Nilai & Jumlah & Presentase \\
\hline$X>90$ & Sangat Baik & 4 & $13 \%$ \\
$75<X \leq 90$ & Baik & 23 & $77 \%$ \\
$60<X \leq 75$ & Cukup & 3 & $10 \%$ \\
$50<X \leq 60$ & Kurang & 0 & $0 \%$ \\
$X \leq 50$ & Sangat Kurang & 0 & $0 \%$ \\
\hline Total & & 30 & $100 \%$ \\
\hline
\end{tabular}

Tabel 5 memberikan gambaran bahwa dari 30 guru, sebanyak 13\% atau 4 guru kemampuannya dalam melaksanakan penilaian menurut Kurikulum 2013 berada pada kategori sangat baik. Sementara $77 \%$ atau 23 guru masuk dalam kategori baik dan sisanya $10 \%$ atau 3 guru masuk dalam kategori cukup. Pada data tersebut tidak ada guru yang masuk dalam kategori kurang dan sangat kurang. Dengan demikian dapat disimpulkan lebih dari $50 \%$ guru kemampuannya dalam penilaian pembelajaran matematika menurut Kurikulum 2013 pada kelas XII SMA Negeri di Kota Pekanbaru berada pada kategori baik. Temuan tersebut juga sejalan dengan hasil penelitian Putri (2015) bahwa dalam kurun waktu 2 tahun implementasi Kurikulum 2013 untuk guru matematika SMA sudah ada peningkatan kualitas dalam menyusun penilaian pembelajaran, meskipun masih ada beberapa kekurangan pada penilaian otentik.

\section{Hasil Observasi dan Wawancara}

Observasi dilakukan kepada seluruh responden yang merupakan sampel sekaligus populasi dalam penelitian. Sementara wawancara dilakukan kepada 8 responden yang juga merupakan wakil dari setiap sekolah penelitian. Hasil analisis observasi dan wawancara disajikan pada Tabel 6. 
PYTHAGORAS: Jurnal Pendidikan Matematika, 14 (1), 2019 - 87

Jaya Paldi, Jailani

Tabel 6. Hasil Analisis Data Observasi dan Wawancara

\begin{tabular}{|c|c|c|}
\hline Hasil Reduksi dan Penyajian Data & Tema & Keterkaitan antar Tema \\
\hline $\begin{array}{l}\text { RPP dibuat dari hasil adaptasi RPP hasil kajian } \\
\text { MGMP. }\end{array}$ & \multirow{4}{*}{$\begin{array}{l}\text { Secara umum perenca- } \\
\text { naan pembelajaran } \\
\text { sudah baik, namun } \\
\text { masih ada beberapa } \\
\text { kekurangan yaitu terkait } \\
\text { dengan penyusunan } \\
\text { langkah pembelajaran } \\
\text { dan alokasi waktu }\end{array}$} & \multirow{12}{*}{$\begin{array}{l}\text { Keterlaksanaan standar proses } \\
\text { dalam pembelajaran matematika } \\
\text { menurut Kurikulum } 2013 \text { kelas XII } \\
\text { dalam kategori baik, berdasarkan } \\
\text { aspek perencanaan, masuk dalam } \\
\text { kategori baik, meskipun terdapat } \\
\text { kekurangan pada penyusunan } \\
\text { LKS, langkah RPP dan alokasi } \\
\text { waktu, pada aspek pelaksanaan } \\
\text { masuk dalam kategori baik, } \\
\text { meskipun masih terdapat } \\
\text { kekurangan pada kemauan guru } \\
\text { menerapkan pendekatan saintifik } \\
\text { yaitu pada tahap menanya dan } \\
\text { menalar, dan pada aspek } \\
\text { penilaian sudah masuk kategori } \\
\text { baik, meskipun ada kekurangan } \\
\text { penilaian sikap dan keterampilan }\end{array}$} \\
\hline $\begin{array}{l}\text { Secara keseluruhan RPP yang dibuat oleh } \\
\text { responden sudah baik secara komponen dan } \\
\text { kualitas. }\end{array}$ & & \\
\hline $\begin{array}{l}\text { Masih banyak LKS yang kurang sesuai dengan } \\
\text { RPP terutama pada kesesuaian } \\
\text { metode/model/pendekatan pembelajaran } \\
\text { yang digunakan }\end{array}$ & & \\
\hline $\begin{array}{l}\text { Beberapa responden merasa kesulitan dalam } \\
\text { menyusun langkah pembelajaran dan alokasi } \\
\text { waktu. }\end{array}$ & & \\
\hline $\begin{array}{l}\text { Pelaksanaan pembelajaran oleh responden } \\
\text { sudah cukup sesuai dengan RPP yang dibuat. }\end{array}$ & \multirow{4}{*}{$\begin{array}{l}\text { Pelaksanaan pembe- } \\
\text { lajaran sudah cukup } \\
\text { baik, namun terdapat } \\
\text { kesulitan dalam mene- } \\
\text { rapkan pendekatan sain- } \\
\text { tifik dan memantau } \\
\text { kemajuan siswa }\end{array}$} & \\
\hline $\begin{array}{l}\text { Masih banyak guru yang tidak menggunakan } \\
\text { pendekatan saintifik dalam pembelajaran }\end{array}$ & & \\
\hline $\begin{array}{l}\text { Guru kesulitan pada tahap menanya dan } \\
\text { menalar dalam pendekatan saintifik }\end{array}$ & & \\
\hline $\begin{array}{l}\text { Sulit untuk memantau kemajuan seluruh } \\
\text { siswa selama proses belajar }\end{array}$ & & \\
\hline Penilaian Kurikulum 2013 sangat kompleks & \multirow{4}{*}{$\begin{array}{l}\text { Penilaian pembelajaran } \\
\text { dirasakan terlalu kom- } \\
\text { pleks, terutama untuk } \\
\text { penilaian sikap dan } \\
\text { keterampilan }\end{array}$} & \\
\hline Penilaian Menggunakan bantuan IT & & \\
\hline $\begin{array}{l}\text { Penilaian pada sikap dan keterampilan tidak } \\
\text { terpantau dengan baik }\end{array}$ & & \\
\hline Penilaian diri pada aspek sikap tidak objektif & & \\
\hline
\end{tabular}

Hasil Wawancara

Dalam pengembangan RPP diperoleh informasi bahwa guru tidak mengembangkan RPP secara mandiri. RPP yang dimiliki adalah RPP hasil dari forum MGMP. RPP yang dimiliki juga tidak menjadi acuan dalam melaksanakan pembelajaran. Menurut responden, RPP tersebut hanya sebagai syarat administrasi dan pelaksanaan pembelajaran disesuaikan sendiri oleh guru. Sebagian besar guru sebenarnya masih mengalami kesulitan dengan pembelajaran saintifik dan model-model yang dianjurkan oleh pemerintah. Hampir semua guru menggunakan model kooperatif sebagai model yang dianjurkan pemerintah dalam penerapan Kurikulum 2013. Ketika guru ditanya model lain seperti project based learning, discovery learning, problem based learning, bahkan sebagian guru tidak memiliki pengetahuan tentang sintaks model tersebut, dan sebagian responden yang lain mengaku merasa kesulitan jika harus menggunakan model tersebut. Hal ini sesuai dengan Susanah dan Jailani (2016) yang menyatakan bahwa pengetahuan guru tentang pendekatan dan model pembelajaran yang sesuai dengan Kurikulum 2013 masih sangat kurang. Sementara menurut Retnawati (2015) juga menyatakan bahwa hambatan guru matematika dalam implementasi Kurikulum 2013 adalah guru kesulitan dalam menyusun perangkat (RPP dan LKS) terutama pada model sehingga siswa mampu belajar secara aktif di kelas. Ketika guru ditanya model lain seperti project based learning, discovery learning, problem based learning, bahkan sebagian guru tidak memiliki pengetahuan tentang sintaks model tersebut, dan sebagian responden yang lain mengaku merasa kesulitan jika harus menggunakan model tersebut. Meskipun guru merasa sulit dalam menyusun RPP dan LKS, namun melalui proses yang panjang yaitu keikutsertaan dalam forum MGMP dan pelatihan, guru berhasil menyusun RPP dan LKS dengan baik.

Dari hasil wawancara juga diperoleh informasi bahwa proses pembelajaran di kelas tidak selalu menggunakan pendekatan saintifik. Melihat banyaknya cakupan materi yang harus disampaikan kepada siswa dan waktu sudah mendekati ujian nasional, akhirnya membuat guru tidak menggunakan pendekatan saintifik dalam pembelajaran dan kembali ke metode konvensional. Menurut guru, selain alasan tersebut, siswa juga belum terbiasa untuk 
menalar dalam menemukan konsep sendiri sehingga waktu yang dibutuhkan menjadi lebih lama padahal masih banyak materi yang belum disampaikan. Selain itu ada beberapa materi yang sulit untuk diimplementasikan dengan pendekatan saintifik, contoh yang diberikan guru adalah materi vektor yang menurut guru masih sulit untuk diterapkan pendekatan saintifik. Retnawati (2015) juga menyimpulkan dalam penelitiannya tentang hambatan guru matematika dalam melaksanakan pembelajaran menurut Kurikulum 2013 adalah waktu yang terbatas serta mengaktifkan kelas. Selain itu ada beberapa materi kelas XII yang sulit untuk diimplementasikan dengan pendekatan saintifik, contoh yang diberikan guru adalah materi vektor yang menurut guru masih susah untuk diterapkan pendekatan saintifik. Selain itu, Ayu dan Dhoriva (2015) menyatakan bahwa banyak siswa kelas XII yang kesulitan dalam menyelesaikan masalah berkenaan dengan materi kelas XII.

Dalam penilaian pembelajaran, semua responden mengaku bahwa penilaian dalam Kurikulum 2013 terlalu kompleks sehingga menyita banyak waktu dan tenaga. Berdasarkan informasi dari responden, guru tidak selalu melakukan penilaian di setiap pembelajaran karena terkendala waktu dan tenaga. Observasi dilakukan setiap pembelajaran, tetapi hasil observasi tidak langsung ditulis. Penilaian diri dan penilaian teman sejawat juga hanya dilakukan beberapa kali. Menurut seorang responden penilaian diri dan penilaian teman sejawat cenderung tidak objektif karena hasil yang diperoleh relatif sama. Siswa cenderung membuat kesepakatan dalam mengisi penilaian diri dan penilaian teman sejawat sehingga hasil yang diperoleh setiap siswa adalah baik dan sangat baik.

Sebagian besar guru menentukan hasil akhir penilaian dengan menggunakan aplikasi software komputer. Nilai yang diperoleh dimasukkan dalam aplikasi dan langsung memperoleh hasil akhir. Guru mengaku tidak mengetahui secara manual dalam menentukan nilai akhir tersebut. Bahkan terdapat responden mengaku kesulitan menggunakan aplikasi tersebut karena keterbatasan kemampuan dalam bidang informasi dan teknologi (IT) sehingga dalam pelaksanaan penilaiannya meminta bantuan guru yang lain. Hal ini sesuai dengan penelitian Dandis (2013) dan Retnawati (2015) yang menyatakan bahwa penilaian dalam Kurikulum 2013 yang rumit dan membutuhkan waktu yang lama dalam menyusun laporan penilaian.

\section{Hasil Observasi}

Ada 30 guru yang dijadikan sampel penelitian untuk teknik observasi. Di sekolah 1, 2, 3, 4, 5, dan 6 masingmasing terdapat 4 guru yang diobservasi. Sementara untuk Sekolah 7 dan 8 masing-masing 3 guru yang diobservasi. Masing-masing guru yang diobservasi adalah guru kelas XII baik IPA, IPS, maupun Bahasa. Hasil rata-rata dari observasi dalam pembelajaran masuk dalam kategori baik, meskipun masih banyak guru yang masuk dalam kategori cukup dalam melaksanakan pembelajaran matematika.

Berdasarkan hasil observasi diperoleh bahwa 22 guru sudah menggunakan pendekatan saintifik, namun sisanya 8 guru tidak menggunakan pendekatan saintifik. Dalam proses pembelajaran sebagian besar guru sudah melaksanakan proses pembelajaran sesuai dengan RPP yang telah disusun. Meskipun ada beberapa komponen RPP yang tidak ditampilkan dalam pembelajaran. Beberapa guru pada awal pembelajaran tidak menyampaikan manfaat materi pembelajaran yang berhubungan dengan kehidupan sehari-hari. Sebagian besar materi observasi adalah matriks dan vektor, dan pada materi tersebut banyak guru yang tidak menyampaikan manfaat materi matriks dan vektor dalam kehidupan sehari-hari, namun lebih berkosentrasi pada konsep materi. Selain itu pada tahap menanya dan menalar, guru masih kurang luwes dalam pembelajaran, dikarenakan respons dari siswa yang kurang aktif.

Temuan lain dari hasil observasi adalah kurangnya usaha guru dalam melibatkan siswa dalam pemanfaatan media. Aspek lain yang menurut penilaian peneliti masih kurang dalam pembelajaran adalah memantau kemajuan belajar selama proses. Pada RPP yang diberikan guru kepada peneliti memuat komponen penilaian pengetahuan, sikap dan keterampilan. Namun hingga akhir pembelajaran, lembar penilaian yang dipakai guru adalah sebagian besar penilaian pengetahuan, sementara penilaian sikap dan keterampilan masih kosong dan tidak digunakan. Hal lain yang menjadi perhatian peneliti adalah guru tidak memberikan penguatan baik tes tertulis maupun lisan. Guru sebatas mengkonfirmasi pengetahuan siswa melalui pertanyaan hasil pembahasan, namun tidak menggunakan soal/masalah lain untuk menguatkan pengetahuan siswa.

\section{Hasil Telaah Dokumen}

Teknik dokumentasi dilakukan dengan cara menelaah dokumen RPP dan LKS dari 30 responden penelitian yang hasilnya telah disampaikan di dalam hasil penelitian kuantitatif. Selain menelaah dokumen RPP, peneliti juga melakukan studi dokumen lebih mendalam. Hasil studi dokumen menunjukkan bahwa sebagian besar RPP yang 
digunakan adalah RPP hasil dari MGMP. Meskipun seperti itu, masih ada RPP yang masih dalam kategori kurang. Sebagian besar RPP yang masuk dalam kategori kurang adalah tidak sesuainya antara model/metode/pendekatan dengan langkah pembelajaran yang dilakukan. Selanjutnya, beberapa responden tidak menuliskan secara detail pada kegiatan inti. Beberapa responden hanya menuliskan garis besar kegiatan yang akan dilakukan yang sebenarnya masih bisa diperinci sehingga akan memudahkan responden dalam melaksanakan pembelajaran. Selain itu beberapa responden belum menggunakan kata kerja operasional pada rumusan indikator. Hal ini senada dengan penelitian yang dilakukan oleh Nurmalasari, Wati, Puspitasari, Diana, dan Dewi (2015) tentang peran guru dalam Kurikulum 2013 yaitu merinci kegiatan dalam RPP, ini juga yang menjadi kendala bagi guru dalam penyusunan RPP. Sulistyani dan Retnawati (2015) juga menyatakan bahwa guru berkewajiban menyusun RPP yang lengkap dan sistematis. Selain itu, beberapa responden juga belum menggunakan kata kerja operasional dalam menyusun rumusan indikator. Sementara LKS masih banyak yang belum sesuai dengan RPP yang telah dibuat. Terutama keselarasan model/metode/pendekatan yang digunakan dalam RPP belum terintegrasi pada LKS. Lembar kerja siswa yang dibuat hanya berisikan soal-soal tanpa adanya langkah kerja siswa yang diintegrasikan dengan model/ metode/pendekatan yang dipilih.

Selain menelaah RPP, peneliti juga menelaah LKS yang dibuat oleh responden. Sebagian besar responden tidak begitu memperhatikan kualitas LKS, kebanyakan mahasiswa hanya konsentrasi pada kualitas RPP sehingga terkesan LKS yang dibuat hanya sebagai pelengkap saja. Lembar kerja siswa yang telah dibuat oleh beberapa responden hanya berisikan soal-soal saja, tidak memuat langkah-langkah kerja siswa. Selain itu, beberapa LKS yang dibuat tidak selaras dengan RPP yang dibuat. Model atau pendekatan yang digunakan dan tercantum di RPP tidak terintegrasi pada LKS. Sehingga masih banyak LKS yang dibuat responden dalam kategori kurang.

\section{SIMPULAN}

Berdasarkan hasil penelitian dan pembahasan dapat disimpulkan bahwa keterlaksanaan standar proses pada pembelajaran matematika menurut Kurikulum 2013 di SMA Negeri pada kelas XII di Kota Pekanbaru masuk dalam kategori baik. Perencanaan pembelajaran yang terdiri dari keterampilan menyusun RPP dan LKS masuk dalam kategori baik. Pelaksanaan pembelajaran yang meliputi keterampilan melaksanakan pembelajaran dan kesesuaian pembelajaran dengan RPP masuk dalam kategori baik. Penilaian pembelajaran masuk dalam kategori baik. Hasil penelitian juga menunjukkan bahwa pada aspek perencanaan pembelajaran masih terdapat kekurangan pada aspek penyusunan LKS, RPP, serta perencanaan alokasi waktu. Pada aspek pelaksanaan pembelajaran masih terkendala pada kemauan guru untuk menerapkan pendekatan saintifik, terutama pada tahap menanya dan menalar. Adapun pada aspek penilaian, guru masih mengalami kendala terkait penilaian sikap dan keterampilan.

Berdasarkan simpulan penelitian, terdapat beberapa saran dari peneliti. Pertama, guru hendaknya diberikan pelatihan yang lebih masif terkait penyusunan RPP dan LKS yang sesuai dengan Kurikulum 2013. Pelatihan yang diadakan oleh pemerintah saat ini cakupannya masih sangat terbatas, sehingga banyak guru yang belum memiliki wawasan yang cukup untuk membuat perencanaan pembelajaran sesuai dengan Kurikulum 2013. Kedua, guru sebagai ujung tombak pendidikan hendaknya juga harus terus berusaha untuk meningkatkan kapasitas dan kemampuannya sebagai tenaga pendidik yang profesional, baik itu dengan mengikuti berbagai kegiatan seminar pendidikan maupun memanfaatkan berbagai sumber informasi maupun referensi ilmiah seperti jurnal pendidikan. Ketiga, pemerintah dalam hal ini melalui dinas pendidikan di tingkat daerah, sebaiknya berkoordinasi dengan pihak sekolah untuk melakukan pemantauan terhadap keterlaksanaan standar proses, khususnya dalam pembelajaran matematika. Keempat, peneliti lain diharapkan melakukan penelitian serupa dengan melibatkan populasi yang lebih luas, sehingga memungkinkan generalisasi yang lebih luas pula terkait dengan keterlaksanaan standar proses pendidikan.

\section{DAFTAR PUSTAKA}

Abrory, M. (2014). Evaluasi implementasi Kurikulum 2013 pada pembelajaran matematika SMP negeri kelas VII di Kabupaten Sleman (Magister theses, Universitas Negeri Yogyakarta). Retrieved from http://eprints.uny.ac.id/id/eprint/12599

Ayu, A., \& Dhoriva, U. W. (2015). Analisis kesulitan siswa SMA dalam pemecahan masalah matematika kelas XII IPA di Kota Yogyakarta. Jurnal Riset Pendidikan Matematika, 2(1), 28-39. doi: http://dx.doi.org/10.21831/jrpm.v2i1.7148 
Creswell, J. D. (2009). Research design (qualitative, quantitative, and mixed methods approaches). Thousand Oaks, CA: Sage Publications.

Dakir, D. (2010). Perencanaan dan pengambangan kurikulum. Jakarta: Rineka Cipta

Dandis, M. A. (2013). The assessment methods that are used in a secondary mathematics class. Journal for Educators, Teachers and Trainers, 4(2), 133-143. Retrieved from https://www.ugr.es/ jett/pdf/vol04(2)_Maha_Dandis.pdf

Enika, W. (2015). Kesiapan guru matematika smp di kota Yogyakarta dalam melaksanakan kurikulum 2013 (Magister theses, Universitas Negeri Yogyakarta). Retrieved from http://eprints.uny.ac.id/id/eprint/33720

Festiyed, F. (2015). Studi pendahuluan pengimplementasian Kurikulum 2013 dalam mengintegrasikan pendekatan saintifik melalui model inkuiri dan authentic assessment dalam pembelajaran IPA di Kota Padang. Prosiding, Seminar Nasional dan Rapat Tahunan oleh FMIPA Universitas Tanjungpura. Pontianak: Universitas Tanjungpura.

Hidayat, S. (2013). Pengembangan kurikulum baru. Bandung: PT Remaja Rosdakarya

Kemendikbud. (2013). Peraturan Menteri Nomor 65, Tahun 2013, tentang Standar Standar Proses.

Kristiyani, D. (2015). Implementasi Kurikulum 2013 pada pembelajaran matematika SMPN di eks Karesidenan Pati. (Magister theses, Universitas Negeri Yogyakarta). Retrieved from http://eprints.uny.ac.id/id/eprint/20954

Miles, M. B., \& Huberman, A. M. (1994). Qualitative data anlysis. Thousand Oaks,CA: SAGE Publications.

Mullis, I. V. S., Martin, M. O., Foy, P., \& Hooper, M. (2016). TIMSS 2015 international results in mathematics. Boston, MA: TIMSS \& PIRLS International Study Center. Retrieved from http://timssandpirls.bc.edu/timss2015/internationalresults/

Mulyasa, E. (2013). Standar kompetensi dan sertifikasi guru. Bandung: Remaja Rosdakarya.

Muskin, J. A. (2015). Student learning assessment and the curriculum: Issues and implications for policy, design and implementation. Geneva: UNESCO International Bureau of Education (IBE). Retrieved from http://www.ibe.unesco.org/sites/default/files/resources/ipr1-muskin-assessmentcurriculum_eng.pdf

Nurmalasari, R., Wati, R. D. P., Puspitasari, P., Diana, W., \& Dewi, N. K. (2015). Peran guru dalam implementasi Kurikulum 2013. Jurnal Manjemen Pendidikan, 25(5), 722-733. Retrieved from http://ap.fip.um.ac.id/wpcontent/uploads/2016/03/55-Riana-Nurmalasari-Reta-Dian-Purnama-Wati-Poppy-Puspitasari.pdf

Putri, A. H. (2015). Pelaksanaan Kurikulum 2013 pada SMA negeri di Kabupaten Jepara. (Magister theses, Universitas Negeri Semarang). Retrieved from https://lib.unnes.ac.id/20637/

Republik Indonesia. (2003). Undang-Undang Republik Indonesia Nomor 20 Tahun 2003, tentang Sistem Pendidikan Nasional.

Retnawati, H. (2015). Hambatan guru matematika sekolah menengah pertama dalam menerapkan kurikulum baru. Cakrawala Pendidikan, 34(3), 390-403. doi: http://dx.doi.org/10.21831/cp.v3i3.7694

Sanjaya, W. (2010). Strategi pembelajaran berorientasi standar proses pendidikan (7th ed.). Jakarta: Prenada Media Group.

Sulistyani, N., \& Retnawati, H. (2015). Pengembangan perangkat pembelajaran bangun ruang di SMP dengan pendekatan problem based-learning. Jurnal Riset Pendidikan Matematika, 2(2), 197-210. doi: http://dx.doi.org/10.21831/jrpm.v2i2.7334

Susanah, W., \& Jailani. (2016). Kesiapan guru matematika SMP di Purworejo dalam implementasi Kurikulum 2013. Phytagoras: Jurnal Pendidikan Matematika, 11(1), 77-90. doi: http://dx.doi.org/10.21831/pg.v11i1.9675

OECD. (2016). Mathematics performance among 15-year-olds in PISA 2015 results (volume l): Excellence and equity in education. Paris: OECD Publishing. doi: https://doi.org/10.1787/9789264266490-9-en

UNESCO. (2012). EFA global monitoring report: Youth and skills putting education to work. Paris: UNESCO Publishing: Retrieved from https://unesdoc.unesco.org/ark:/48223/pf0000218003 
PYTHAGORAS: Jurnal Pendidikan Matematika, 14 (1), 2019 - 91

Jaya Paldi, Jailani

Zurqoni, Retnawati, H., Apino, E., \& Anazifa, R. D. (2018). Impact of character education implementation: A goal-free evaluation. Problems of Education in the 21st Century, 76(6), 881-899. doi: http://doi.org/10.33225/pec/18.76.881

Zurqoni, Retnawati, H., Arlinwibowo, J., \& Apino, E. (2018). Strategy and Implementation of character education in senior high schools and vocational high schools. Journal of Social Studies Education Research, 9(3), 370-397. Retrieved from https://jsser.org/index.php/jsser/article/view/294 